\title{
Correction to: The Unrealized Potential of National Human Rights Institutions in Business and Human Rights Regulation: Conditions for Effective Engagement and Proposal for Reform
}

\author{
René Wolfsteller ${ }^{1}$ (D) \\ Published online: 29 November 2021 \\ (c) Springer Nature B.V. 2021
}

\section{Correction to: Human Rights Review https://doi.org/10.1007/s12142-021-00639-9}

An uncorrected proof was originally published for this article; it has now been replaced by the corrected version.

The original article has been corrected.

Publisher's Note Springer Nature remains neutral with regard to jurisdictional claims in published maps and institutional affiliations.

The original article can be found online at https://doi.org/10.1007/s12142-021-00639-9

René Wolfsteller

Rene.wolfsteller@politik.uni-halle.de

1 Department of Political Science, Martin-Luther-Universität Halle-Wittenberg, 06099 Halle (Saale), Germany 